\title{
NOTES TO THE READER
}

- Numbers in brackets indicate document numbers found in this text.

- Different calendars in different kingdoms and city-states began at different times - some at Christmas, some at Easter, and some on 25 March. I have put the years in the original and then added in brackets the year corresponding to our calendar if different from the original. Thus, an event in Florence that occurred on 24 March 1389 would be rendered 24 March $1389[90]$.

- If I have left out text from the original, I have indicated it with '...'; if text is missing from the original source, I have indicated it with ' $[\ldots]$ '.

- In Latin texts from Italy I have translated proper names into Italian; in those from France, into French.

- I have left 'Messer' (meaning lord) in the original for Italian patronymics but translated it as Lord for the first name.

- For certain obscure or problematic place names and phrases I have given the medieval original in brackets.

- For certain key words, for instance, for 'people', 'commoners', 'rabble', 'revolt', 'rebel', 'rebellion', I often provide the original in brackets.

- Most of the place names in these documents appear on one of the six maps; for the others I have specified their location in the notes.

- For currencies and their equivalences I have provided notes, but for further elucidation the reader should consult the tables in Peter Spufford, Money and its Use in Medieval Europe (Cambridge, 1988), especially Table 4, pp. 291-3, and graph 3, pp. 296-8.

- For well-known people I have translated Christian names, thus King John II, instead of King Jean, but for others I have left the variants found in the texts, Jean, Jehan, Giovanni, Giano, etc.

- The twenty-four-hour clock of the Middle Ages began at vespers, which at Florence would have been 19:45 at the summer solstices. In translating the summer hours (the vast majority found in these documents) I have rounded the time of vespers to 20:00 and have calculated the others accordingly. 